\title{
Academic community sets agenda to reclaim scholarly publishing
}

Universities have it within their power to work with each other and scholarly societies to transform scholarly conmunication into "a system of electronically mediated publications that will provide enhanced access to scholarly information and relief from the escalating prices of commercial publishers." So concluded the participants-university presidents, provosts, faculty, librarians, counsels, and representatives of scholarly societies and university presses-in a special Roundtable on Managing Intellectual Property in Higher Education. The findings of this group were reported in the essay "To Publish and Perish," featured in the March 1998 issue of Policy Perspectives, the publication of the Pew Higher Education Roundtable.

Noting that the rising cost of scholarly publications is not a "library problem," but a symptom of the deeper conflict between the sociology and economics of academic publishing, the essay contrasts the expectation of an open exchange of information within the academy to the pricing and copyright practices of some commercial publishers that control many of the major scholarly publishing venues. In an effort to regain some control over the research and scholarship generated by the academic community, the Roundtable participants proposed a set of five strategies to address the problem, in- cluding the disentangling of quantity and quality in faculty work, the leveraging of library resources through consortial purchasing, educating faculty and administrators on the economics of scholarly publishing, investing in electronic forms of publishing, and decoupling peer reviewed evaluation from publication.

The Roundtable was hosted by the Johns Hopkins University and sponsored by the Association of American Universities (AAU), the Association of Research Libraries (ARL), and the Pew Higher Education Roundtable. Funding was provided by the Gladys Krieble Delmas Foundation, the W. K. Kellogg Foundation, and The Pew Charitable Trusts.

ARL in conjunction with the AAU and other organizations is pursuing a number of the recommendations in the report and has developed a Web site to track progress. To encourage broad discussion of the issues raised, ARL is also seeking the participation of the academic library community in developing a clearinghouse of responses to and experiences in the use of the report in discussions on campus and in the broader community. To obtain a copy of the report, share comments, relate experiences, or track progress, see http://www.arl.org/scomm/ pew/.-Mary Case, Association of Research Libraries, e-mail: marycase@arl.org. viewed by a panel of IS and DIS members.

\section{November 1 deadline for ACRL poster sessions}

November 1, 1998, is the deadline for submitting a proposal for a poster session at ACRL's 9th National Conference, April 8-11, 1999, in Detroit. Submission details may be found on the Web at: http:// www.ala.org/acrl/ calluprt.html.

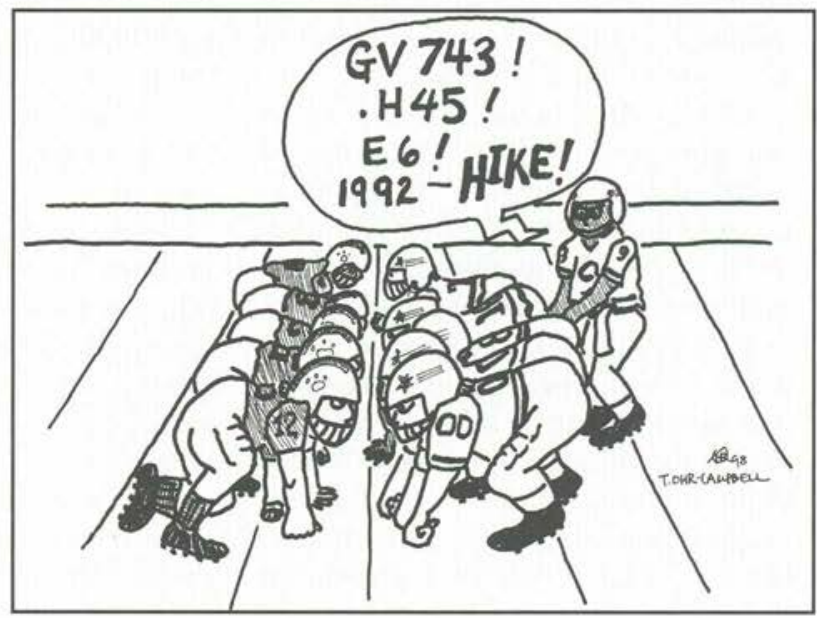

